\title{
Paradigma Holistik-Integratif-Interkonektif Dalam Filsafat Manajemen Pendidikan Karakter
}

\author{
Maragustam \\ UIN Sunan Kalijaga \\ margustam22@gmail.com
}

\begin{abstract}
This paper analyzes the thought of philosophy of education management character of the nation with a philosophical method. The results of the discussion can be concluded that it needed a new paradigm in the management philosophy of education that is holisticintegrative character-interkonektif. The essence of management lies in POAC (planning, organizing, actuating and controlling). In character education management philosophy with the new paradigm is to be done thoroughly, connectedness and relatedness between one system with other systems. As a holistic-integrative-interkonektif in the level of strategy (habituation, moral knowing, moral loving-feeling, exemplary and repentance), the level of educational institutions (formal, informal and non-formal), the level of the main values of character, level kurkukulum (intra-curricular, extra curricular and hidden curriculum), the level of age (early childhood, adolescence, adulthood, and old age) and the level of mental gymnastics (if thought, hearts, taste-intention, spiritual and physical). With this paradigm, the management philosophy of character education will form a good character-solid man who is ready to face the impact of globalization is challenging and uncertain particularly negative impact.
\end{abstract}

Keywords: character education management, paradigm, and holistic-integrativeintercontective.

\section{A. Pendahuluan}

Kemajuan Ilmu pengetahuan dan teknologi (Iptek) dibidang transportasi dan informasi menjadikan belahan dunia semakin kecil dan mengglobal. Namun di sisi lain, dengan perbedaan perspektif terhadap nilai-nilai etika dan spritual, menjadikan manusia kehilangan pegangan hidup dan karakter. Diantara akibat negatif dari era global ini, ialah nilai-nilai spiritualitas agama bukan saja tidak diamalkan, tetapi menjadi momok dalam kehidupan. Nilai-nilai agama terpisah dari kehidupan. Agama hanya untuk akhirat, sementara urusan dunia tidak berkaitan dengan agama. Dengan kemajuan iptek, menjadikan sebagian masyarakat menjauh dari nilai-nilai luhur agama, falsafah bangsa dan budayatradisi. Bahkan telah membebaskan manusia dari serba Tuhan, nilai budaya dan nilai-nilai falsafah bangsanya. Karena tidak mengindahkan nilai-nilai luhur (nilai agama, nilai sosial budaya dan nilai filsafat bangsa), maka keadaan masyarakat 
akan dikendalikan oleh paham liberalisme, hedonisme, dan sekuralisme. Pahampaham tersebut tumbuh diantaranya akibat dari pengaruh negatif arus globalisasi yang masuk ke lorong-lorong kehidupan. Arus globalisasi di satu sisi membawa manfaat dalam kehidupan yakni mempermudah dalam segala bidang kehidupan. Namun di sisi lain arus globalisasi membawa dampak negatif. Diantara sisi negatif dari globalisasi ialah (1) kecenderungan modernisme itu untuk massifikasi, penyeragaman manusia dalam dalam segala bidang, menempatkan semua orang sebagai mesin atau sekrup dari sebuah sistem rasional; (2) sekularisme, yang berarti tidak diakuinya lagi adanya ruang nafas buat yang Ilahi, atau dimensi religius dalam hidup, (3) orientasi nilainya yang menomorsatukan instant solution, resep jawaban tepat, cepat, langsung, (4) liberalisme, yang berarti faham freedom of choice yang meliputi freedom of worship, ownership, politics, and ekspression dan (5) hedonisme yakni kebahagiaan adalah kesenangan. Kesenangan itu berkat gerakan yang lemah gemulai, sedangkan rasa sakit berkat gerakan kasar. Kesenangan sesaat yang dinikmati itulah yang dihargai. Suatu perbuatan disebut baik sejauh dapat menyebabkan kesenangan dan memberi kenikmatan ragawi.

Dalam kondisi yang demikian mental seseorang tidak lagi dapat membedakan mana yang real dan mana yang tidak; mana yang sifatnya kebutuhan (need) dan mana pula yang sifatnya keinginan (want). Ilmu pengetahuan dan teknologi bukan lagi berfungsi sebagai sarana mendekatkan diri kepada Tuhan dan mengembangkan peradaban. Tetapi Iptek tersebut berfungsi sebagai sarana memperoleh kenikmatan ragawi dan kepuasan syahwat. Iptek meningkat posisinya seolah menjadi "agama baru" sehingga banyak diantara manusia yang mempertuhankannya. Albert Enstein mengatakan bahwa science without religion is blind but religion without science is lame. Dalam posisi ini manajemen pendidikan Islam pun semakin sulit jika top leader (pemimpin) pendidikan tidak mau merubah mindset (pola pikir-hati) dengan paradigma holistik-integratifinterkonektif dalam pembentukan karakter.

Jika manusia telah dikendalikan oleh keinginan dan syahwat, maka suatu bangsa akan hancur. Karena bangsa jika dikendalikan orang yang bermental tuna 
karakter, perjalanan bangsa itu berdiri di atas pilar kegelapan yang sewaktu-waktu akan terjatuh. Jika seseorang pun berbuat baik pada saat ini, bukan karena mentalnya baik, tetapi karena keadaan memaksanya (motivasi ekstrinsik) untuk berbuat baik. Jika motivasi ekstrinsik sebagai basisnya, tentu tidak akan bertahan lama. Pada posisi ini revolusi mental perlu dilakukan dan mental itu pusatnya adalah manusianya bukan system atau sarana prasaranya. Hakikat manusia itu ialah mental (akal, hati, keyakinan dan nafsu) dan ragawi. Dengan rapuhnya mentalitas masyarakat Indonesia ini maka dibutuhkan paradigma holistikintegratif-interkonektif dalam filsafat manajemen pendidikan kakrakter di lembaga pendidikan Islam.

\section{B. Kajian Pustaka}

Paradigma pada hakikatnya adalah asumsi-asumsi dasar dan teoritis yang umum sehingga merupakan sumber nilai, hukum-hukum, metode serta penerapan dalam manajemen pendidikan karakter. Istilah paradigma pertama kali dikemukakan oleh Thomas S. Kuhn dalam The Structure of Scientific Revolution. Kuhn mendefinisikan paradigma sebagai pandangan hidup (world-view atau weltanschauung) yang dimiliki oleh ilmuwan dalam suatu disiplin tertentu. Sedang Robert A. Friedrichs dalam Sosiology of Sociology paradigma adalah konsistensi dari proses keilmuan. Sementara hakikat holistik-integrasiinterkoneksi adalah menyeluruh, utuh, saling keterkaitan dan keterhubungan antara satu dengan yang lain sehingga membentuk satu sistem terpadu. Menurut Amin Abdullah bahwa yang perlu didiskusikan ialah kemampuan dosen melalui mata kuliah yang diampu membentuk world view, pandangan dunia keagamaan Islam, nilai-nilai keagamaan Islam yang baru pada diri peserta kuliah/didik dengan cara mengsalingkaitkan dan mengsalinghubungkan antara satu item pembahasan dengan item pembahasan yang lain. Penekanan ini penting karena dalam kesalingketerkaitan dan saling keterhubungan itulah inti pokok paradigma integrasi dan interkoneksi. ${ }^{1}$ Pada gilirannya paradigma holistik-integratif dan

${ }^{1}$ M. Amin Abdullah, Paradigma dan Implementasi Pendekatan Integrasi-Interkoneksi dalam Kajian Pendidikan Islam, (Yogyakarta: Pascasarjana UIN Sunan Kalijaga, 2014), h. 4-5. Baca: Maragustam (editor), Implementasi Pendekatan Integratif-Interkonektif Dalam Kajian Pendidikan Islam, (Yogyakarta: Pascasarjana UIN Sunan Kalijaga, 2014), h. 201. 
interkonektif dalam manajemen pendidikan karakter akan mampu membentuk jaringan pola berpikir yang sistemik, yang membentuk keutuhan world view, pandangan dunia character building yang utuh, komprehensif dan segar. Pandangan dunia pembentukan karakter yang fresh, baru dan transformatif, yang relevan dengan tantangan perubahan sosial dan perkembangan ilmu pengetahuan. Sama halnya memehami Alquran sebenarnya juga harus juga dengan paradigma integrasi dan interkoneksi ilmu sehingga pamahamannya menjadi utuh.

Manajemen berasal dari bahasa Inggris management yang berarti mengurusi. ${ }^{2}$ Menurut Tery, manajemen berarti kemampuan mengarahkan dan mencapai hasil yang diinginkan dengan tujuan dari usaha-usaha manusia dan sumber daya lainnya. Menurut Hersey dan Blanchard; manajemen adalah proses bekerja sama antara individu dan kelompok serta sumber daya lainnya dalam mencapai tujuan organisasi. Reeser berpendapat bahwa manajemen adalah pemanfaatan sumber daya fisik dan manusia melalui usaha yang terkoordinasi dan diselesaikan dengan mengerjakan fungsi perencanaan, pengorganisasian, penyusunan staf, pengarahan, dan pengawasan. $^{3}$ Menurut Sukanto Reksohadipprodjo, manajemen adalah suatu usaha, merencanakan, mengorganisir, mengarahkan, mengkordinir serta mengawasi kegiatan dalam organisasi agar tercapai tujuan organisasi secara efisien dan efektif. ${ }^{4}$ Dari berbagai definisi tersebut maka dapat dijelaskan bahwa manajemen adalah seni untuk mencapai hasil/tujuan yang maksimal dan mencapai kesejahteraan dan kebahagiaan maksimal baik bagi pimpinan maupun para pekerja serta memberikan pelayanan yang sebaik mungkin kepada masyarakat dengan pemanfaatan sumber-sumber daya yang tersedia. Fungsi-fungsi manajemen yang berkaitan dengan pendidikan karakter ialah planning, organizing, directing, coordinating and controlling.

Planning adalah menentukan serangkaian tindakan dan kegiatan untuk mencapai hasil yang diharapkan yakni terbentuknya karakter peserta didik.

\footnotetext{
${ }^{2}$ Sulistyorini, Manajemen Pendidikan Islam (Konsep, Strategi, dan Aplikasi), (Yogyakarta: Sukses Offset, 2009), h. 8. h. 41-43.

${ }^{3}$ Syafaruddin, Manajemen Lembaga Pendidikan Islam, (Jakarta: PT. Ciputat Press, 2005),

${ }^{4}$ Sofwan Manaf, Pola Manajemen Penyelenggaraan Pondok Pesantren, (Jakarta, Dirjen Pembinaan Kelembagaan Agama Islam Depag RI., 2001), h. 1.
} 
Organizing ialah pengelompokan kegiatan untuk mencapai tujuan, termasuk dalam hal ini penetapan susunan organisasi pembentukan karakter, tugas dan fungsinya. Organisasi lebih menekankan pada pengaturan mekanisme kerja. Organizing harus ada proses pembagian kerja ke dalam tugas-tugas yang lebih kecil, memberi tugas-tugas tersebut kepada ahlinya terutama kepada guru agama dan guru PPKn yang sarat dengan nilai dan mengalokasikan sumberdaya, serta mengkoordinasikannya dalam rangka efektivitas pencapaian tujuan. Ditecting/Commanding (pengarahan) ialah usaha memberi bimbingan saran-saran dan perintah dalam pelaksanaan tugas masing-masing bawahan (delegasi wewenang) untuk dilaksanakan dengan baik dan benar sesuai dengan tujuan pembentukan karakter. Coordinating ialah menyelaraskan tugas atau pekerjaan agar tidak terjadi kekacauan dan saling melempar tanggung jawab dengan jalan menghubungkan, menyatupadukan, dan menyelaraskan pekerjaan bawahan. Controlling ialah agar prilaku personalia organisasi mengarah ke tujuan organisasi, bukan semata-mata ke tujuan individual; dan agar tidak terjadi penyimpangan yang berarti antara rencana dengan pelaksanaan. Fungsi pengawasan mencakup; penetapan standar pelaksanaan; penentuan ukuran/indikator keberhasilan pembentukan karakter; pengukuran pelaksanaan, pengambilan tindakan koreksi bila diperlukan, meluruskan yang bengkok, mengoreksi yang salah membenarkan yang hak (yang benar).

Istilah karakter bukanlah hal yang baru bagi kita. Ir. Soekarno, telah menyatakan tentang pentingnya "nation and character building" bagi negara yang baru merdeka. Konsep membangun karakter juga dikumandangkan kembali oleh Soekarno era 1960-an dengan istilah 'berdiri di atas kaki sendiri’ (berdikari). ${ }^{5}$ Karakter barasal dari bahasa Yunani Kharakter yang berakar dari diksi 'kharrasein' yang berarti memahat atau mengukir (to inscribe/to engrave), sedangkan dalam bahasa latin karakter membedakan tanda. ${ }^{6}$ Menurut Simon Philips yang dikutip oleh Masnur Muslich, karakter adalah kumpulan tata nilai

\footnotetext{
${ }^{5}$ Sri Narwati, Pendidikan Karakter, Pengintegrasian 18 Nilai Pembentuk Karakter dalam Mata Pelajaran, (Yogyakarta: Familia, 2011), h. 1.

${ }^{6}$ Ibid., h. 1-2.
} 
yang menuju pada suatu sistem, yang melandasi pemikiran, sikap, dan perilaku yang ditampilkan. ${ }^{7}$

Jiwa manusia bagaikan tanah liat yang siap diukir dan dipahat sesuai dengan karakteristik tanah liat tersebut. Sekeras apapun watak manusia, masih tetap bisa dibentuk sesuai dengan fitrah manusia itu. Pada hakikatnya karakter ialah tabiat; watak; sifat-sifat kejiwaan, akhlak, atau budi pekerti yang membedakan seseorang daripada yang lain. ${ }^{8}$ Karakter adalah sifat utama yang terukir, baik pikiran, sikap, prilaku maupun tindakan, yang melekat dan menyatu kuat pada diri seseorang, yang membedakannya dengan orang lain. Karena karakter tersebut sebuah ukiran dalam jiwa, maka ia sulit untuk diubah. Menurut Mounier yang dikutip Doni Koesoema bahwa karakter dapat dilihat dari dua hal, pertama, sebagai sekumpulan kondisi yang telah diberikan begitu saja, atau telah ada begitu saja, yang lebih kurang dipaksakan dalam diri kita. Karakter yang demikian ini dianggap sebagai sesuatu yang telah ada (given). Kedua, karakter juga bisa dipahami sebagai tingkat kekuatan melalui mana seorang individu mampu menguasai kondisi tersebut. Karakter yang demikian ini disebutnya sebagai sebuah proses yang dikehendaki (willed). ${ }^{9}$ Dari berbagai pengertian tersebut dapat didefinisikan bahwa manajemen pendidikan karakter ialah pengaturan untuk mempatrikan nilai-nilai ke dalam diri peserta didik melalui pendidikan, endapan pengalaman, pembiasaan, pengorbanan, dan rekayasa lingkungan, dipadukan dengan nilai-nilai intrinsik yang sudah ada dalam diri peserta didik sehingga menjadi landasan dalam berpikir, bersikap dan perilaku secara sadar dan bebas dan dilakukan secara integral-interkoneksi.

Seseorang yang didominasi oleh kondisi-kondisi dari sononya (given), maka karakternya akan lemah-negatif. Karena dia tunduk pada sekumpulan kondisi yang telah diberikan kepadanya tanpa dapat menguasainya. Sebaliknya,

\footnotetext{
${ }^{7}$ Masnur Muslich, Pendidikan Karakter, Menjawab Tantangan Krisis Multidimensial, (Jakarta: Bumi Aksara, 2011), h. 70.

${ }^{8}$ W.J.S. Poerwadarminta, Kamus Umum Bahasa Indonesia, (Jakarta: Balai Pustaka, 2005), h. 521. Bandingkan dengan Eko Endarmoko, Tesaurus Bahasa Indonesia, (Jakarta: Gramedia Utama, 2008), h. 290.

${ }^{9}$ Doni Koesoema A, Pendidikan Karakter Strategi Mendidik Anak di Zaman Global, (Jakarta: PT Gramedia, 2010), h. 90-91.
} 
karakter yang baik-kokoh ialah bila seseorang yang tidak mau dikuasai oleh sekumpulan realitas yang ada (given). Orang yang berkarakter dengan demikian seperti seorang yang membangun dan merancang masa depannya sendiri. Ia tidak mau dikuasai oleh kondisi kodratinya yang menghambat perkembangannya. Sebaliknya ia menguasainya, bebas mengembangkannya demi kesempurnaan kemanusiaan dan spiritualitas keagamaannya. Itulah manusia berkarakter baikkokoh.

Basis acuan dalam merumuskan filsafat manajemen pendidikan karakter ialah pada QS. Rum (30): 30. ${ }^{10}$ Dari ayat ini dapat diklasifikasi bahwa bawaan dasar (fitrah) manusia dan proses pembentukan karakternya menjadi empat aliran yaitu (1) fatalis-pasif (2) netral-pasif (3) positif-aktif dan (4) dualis-aktif. ${ }^{11}$ Berbeda dengan apa yang dikemukakan oleh Morris L. Bigge (Barat), ada empat sifat dasar manusia dan hubungannya dengan alam sekitar yaitu bad-active (jelekaktif), good-active (baik-aktif), neutral-passive (netral-pasif) dan neutral interactive (netral-interaktif). ${ }^{12}$ Dalam tulisan ini dua madzhab yang sangat penting kaitannya pembentukan karakter yakni positif-aktif dan dualis-aktif.

Mazhab ini berpandangan bahwa bawaan dasar atau sifat manusia sejak lahir adalah berkarakter baik-kokoh, sedangkan seseorang menjadi berkarakter jahat-lemah adalah bersifat kecelakaaan dan sementara. Artinya seseorang lahir sudah membawa karakter yang baik-kokoh. Karekter baik-kokoh itu bersifat dinamis dan aktif mempengaruhi lingkungan sekitar. Jika seseorang berkatakter jelek-lemah, hal itu karena faktor luar, bukan dari Tuhan, dan bukan pula faktor dalam atau bagian integral dari dirinya. Seperti halnya pohon benalu menumpang di pohon mangga. Pohon mangga tidak akan berubah menjadi pohon benalu. Sebaliknya pohon benalu tidak akan berubah menjadi pohon mangga. Justru yang

\footnotetext{
10,'Maka hadapkanlah wajahmu dengan lurus kepada agama (Allah); (tetaplah atas) fitrah Allah yang telah menciptakan manusia menurut fitrah itu. Tidak ada perubahan pada fitrah Allah. (Itulah) agama yang lurus; tetapi kebanyakan manusia tidak mengetahui."

${ }^{11}$ Maragustam, Mencetak Pembelajar Menjadi Insan Paripurna (Falsafah Pendidikan Islam), (Yogyakarta: Nuha Litera, 2010), h. 92-98. Baca juga: Maragustam, Filsafat Pendidikan Islam Menuju Pembentukan Karakter Menghadapi Arus Global, (Yogyakarta: Kurnia Kalam Semestra, 2015), h. 124-132.

${ }^{12}$ Morris L. Bigge, Learning Theories for Teachers, (USA: Harper and Row, Publisher, Inc, 1982), h.16.
} 
terjadi ialah pohon mangga (yang semula berkarakter baik-kokoh) hidup tertatihtatih bahkan mati sebelum ajal yang sesungguhnya, karena digerogoti secara istiqomah oleh pohon benalu. Hal itu ditunjukkan oleh firman Allah QS. al-A'raf (7):172. Kalimat "Bukankah aku ini Tuhanmu?" mereka menjawab: "Betul (Engkau Tuban kami), Kami menjadi saksi", dimaknai sebagai pemberian Tuhan secara asal kepada setiap individu sesuatu berkarakter baik-kuat. Berarti manusia berasal dari Tuhan adalah berkarakter baik-kokoh, dan menjadi berkarakter jeleklemah di tangan manusia dan polesan lingkungan termasuk pendidikan. Juga firman Allah dalam QS. An Nisa: 79. ${ }^{13}$ Sifat dasar manusia memiliki lebih dari sekedar pengetahuan tentang Allah yang ada secara inheren di dalamnya, tetapi juga suatu cinta kepada-Nya dan keinginan untuk melaksanakan ajaran agama secara tulus sebagai seorang hanif sejati sesuai QS. Ar-Rum (30):30. Menurut ash Shabuni, kebaikan dan kesucian menyatu pada diri manusia, sementara kejahatan bersifat aksidental. Manusia secara alamiah cenderung kepada kebaikan dan kesucian. Akan tetapi, lingkungan sosiallah, terutama orangtua, yang merusak terhadap diri (nafs), akal dan fitrah anak. Menurut Ismail Raji al-Faruqi, bahwa kecintaan kepada semua yang baik dan bernilai merupakan kehendak ketuhanan sebagai sesuatu yang Allah tanamkan kepada manusia. Pengetahuan dan kepatuhan bawaan kepada Allah bersifat alamiah, sementara kedurhakaan tidak bersifat alamiah. ${ }^{14}$ Secara kodrati manusia itu baik, namun masyarakatlah yang membelenggu individu itu sehingga ia menjadi manusia yang bertumbuh semakin menjauhi dari kodratnya. Dari penjelasan ini nampak jelas ada hubungan erat (interkoneksi) antar lembaga pendidikan, kultur politik, budaya dan tradisi, kehidupan sosial, dan pertumbuhan individu.

Shadr berpendapat bahwa QS. Ar-Rum (30):30 ini merupakan pernyataan dan tidak menggariskan sesuatu aturan atau hukum apa pun. Manusia diciptakan sedemikian rupa sehingga agama menjadi bagian dari fitrahnya, dan bahwa

${ }^{13}$ Apa saja nikmat yang kamu peroleh adalah dari Allah, dan apa saja bencana yang menimpamu, maka dari (kesalahan) dirimu sendiri. Kami mengutusmu menjadi Rasul kepada segenap manusia. Dan cukuplah Allah menjadi saksi.

${ }^{14}$ Yasien Mohammad, Insan Yang Suci, Konsep Fitrah Dalam Islam, (Bandung: Mizan, 1997), h. 46. 
ciptaan Ilahi tidak bisa diubah. Agama bukanlah materi budaya yang diperoleh manusia sepanjang sejarah. Agama adalah bagian dari fitrah suci manusia, karenanya manusia tidak bisa hidup tanpanya. ${ }^{15}$ M. Quraish Shihab mengatakan bahwa fitrah manusia adalah kejadiannya sejak semula atau bawaan dasar sejak lahirnya. Para ulama memahaminya dengan tauhid (QS. al-Rum (30): 30). Kata laa (tidak) pada ayat tersebut, berarti bahwa seseorang tidak dapat menghindar dari fitrah. Dalam konteks ayat ini, ia berarti bahwa fitrah keagamaan akan melekat pada diri manusia untuk selama-lamanya, walaupun boleh jadi tidak diakui atau diabaikannya. ${ }^{16}$ Melalui teori positif-aktif, manusia menjadi pelaku yang bertindak serta bereaksi atas dunia di luar dirinya. Dimensi ini berupa disposisi batin melalui mana determinasi ini diterima, ditolak, atau sintesis atau dimodifikasi secara aktif.

Mazhab ini berpandangan bahwa manusia sejak awalnya membawa sifat ganda. Di satu sisi cenderung kepada kebaikan (energi positif), dan di sisi lain cenderung kepada kejahatan (energi negatif). Dua unsur pembentuk esensial dari struktur manusia secara menyeluruh, yaitu ruh dan tanah, mengakibatkan karakter baik-kokoh dan karakter jahat-lemah sebagai suatu kecenderungan yang setara pada manusia, yaitu kecenderungan untuk mengikuti Tuhan berupa nilai-nilai etis spiritual dan kecenderungan mengikuti syetan berupa nilai-nilai a-moral dan kesesatan. Kecenderungan kepada karakter baik-kokoh dibantu oleh energi positif berupa kekuatan spiritual (fitrah tauhid), kenabian dan wahyu Tuhan, bisikan malaikat, kekuatan akal sehat, nafs muthmainnah (jiwa yang tenteram), dan hati yang sehat dalam diri manusia. Sedangkan kecenderungan kepada karakter jahatlemah berupa energi negatif yakni nafsu ammarah bissu' (nafsu yang selalu cenderung destruktif), nafsu lawwamah (nafsu yang tercela dan plin plan/bunglon), kesesatan dan bisikan setan. Energi positif tersebut akan melahirkan berkarakter baik-kokoh., yaitu orang yang punya spiritual, memiliki integritas, komitmen, bersahabat, jujur, dan beramal saleh. Aktualisasi orang yang berkarakter seperti ini dalam hidup dan bekerja akan melahirkan akhlak mulia

\footnotetext{
${ }^{15}$ M. Baqir al-Shadr, Sejarah Dalam Perspektif Al-Qur'an, Sebuah Analisis, (Jakarta: Pustaka Hidayah, 1993), h. 50.

${ }^{16}$ Muhammad Quraish Shihab, Wawasan al-Quran, (Bandung: Mizan, 1997), h. 284-285.
} 
karena memiliki personality (integritas, komitmen dan dedikasi), capacity (kecakapan) dan competency (kemampuan) serta keterampilan. Sedangkan energi negatif tersebut akan melahirkan orang yang berkarakter jahat-lemah, yaitu orang yang selalu mengaktualisasikan dirinya destruktif, bahkan syirk. Aktualisasi orang yang berkarakter seperti ini dalam hidupnya akan menampakkan perilaku tercela, yaitu orang yang memiliki personality tidak bagus (hipokrit alias munafiq alias inkonsisten, penghianat, dan pengecut) dan tidak mampu mendayagunakan potensi yang dimilikinya. Untuk itu ayat "Khatamallah 'ala quluubihim" dalam QS al-Baqarah: 7 (Allah telah mengunci-mati hati mereka), bukanlah Tuhan yang mumulai mengunci mati akal-hati seseorang menjadi berkarakter jahat-lemah, tetapi manusialah yang memulainya lewat pikiran yang dibangunnya dan menuruti tarikan energy negative, faktor luar dan akal bawah sadarnya. Lalu Tuhan merestui kehendak bebas manusia sesuai dengan sunnah-Nya. Disinilah perlu pendekatan integratif-interkonektif dalam manajemen pembentukan karakter.

Tanah yang menjadi simbol terendah dari kehinaan digabungkan dengan ruh kesucian dari Allah adalah pembentuk karakter manusia. Manusia adalah makhluk berdimensi ganda, dengan sifat karakter dasar ganda, tersusun dari dua kekuatan, bukan saja berbeda, tapi juga berlawanan. Yang satu cenderung turun kepada materi (energi negatif) dan yang lain cenderung naik kepada roh suci (energi positif). Kemampuan dan kecenderungan tersebut kemudian saling mempengaruhi secara aktif dengan polesan lingkungan sehingga tumbuh dan berkembang menjadi lebih baik atau lebih buruk. Hal ini dapat dilihat tafsiran dari QS. al-Hijr [15]:28-29) ${ }^{17}$, al-Balad [90]:10) ${ }^{18}$ dan al-Syams [91]:7-10. ${ }^{19}$

Pemilihan dua madzhab tersebut dipahami secara holistik-integratifinterkonektif bahwa pembentukan karakter seseorang sangat tergantung kepada

\footnotetext{
${ }^{17}$ dan (ingatlah), ketika Tuhanmu berfirman kepada Para Malaikat: "Sesungguhnya aku akan menciptakan seorang manusia dari tanah liat kering (yang berasal) dari lumpur hitam yang diberi bentuk. Maka apabila aku telah menyempurnakan kejadiannya, dan telah meniup kan kedalamnya ruh (ciptaan)-Ku, Maka tunduklah kamu kepadanya dengan bersujud.

${ }^{18}$...dan Kami telah menunjukkan kepadanya dua jalan. Yang dimaksud dengan dua jalan ialah jalan kebajikan dan jalan kejahatan.

19 ...dan jiwa serta penyempurnaannya (ciptaannya). Maka Allah mengilhamkan kepada jiwa itu (jalan) kefasikan dan ketakwaannya. Sesungguhnya beruntunglah orang yang mensucikan jiwa itu,
} 
empat hal yakni faktor bawaan, lingkungan, kebebasan dengan mindset seseorang dan faktor hidayah Tuhan. Turunnya hidayah kepada seseorang, pada hakikatnya juga karena keaktifan manusia dari dalam dirinya, lalu Allah menyinari sisi dalam manusia. Bahkan Imam Ibnu Katsir mengatakan bahwa, hidayah ini dibatasi masalah iman saja. Yang dimaksud dengan hidayah ialah sesuatu yang ditetapkan dan dihujamkan ke dalam hati seseorang yakni iman. ${ }^{20}$

Dalam UU Sisdiknas tahun 2003 disebutkan bahwa di antara tujuan pendidikan nasional adalah berkembangnya potensi peserta didik agar menjadi manusia yang beriman dan bertakwa kepada Tuhan Yang Maha Esa, berakhlak mulia, sehat, berilmu, cakap, kreatif, mandiri, dan menjadi warga negara yang demokratis serta bertanggung jawab. Tujuan tersebut sarat dengan nilai karakter. Menurut Diane Tilman, ada dua belas ${ }^{21}$ karakter yang perlu diinternalisasikan dalam manajemen pembentukan karakter yakni (1) kedamaian, (2) penghargaan, (3) cinta, (4) toleransi, (5) kejujuran, (6) kerendahan hati, (7) kerjasama, (8) kebahagiaan, (9) tanggungjawab, (10) kesederhanaan, (11) kebebasan, dan (2) persatuan. $^{22}$ Sedangkan menurut Thomas Lickona, kebajikan-kebajikan yang paling penting bagi manajemen pendidikan karakter yang baik-kuat ada sepuluh yaitu (1) kebijaksanaan (pertimbangan yang baik), (2) keadilan, (3) ketabahan, (4) pengendalian diri, (5) kasih, (6) sikaf positif, (7) kerja keras, (8) ketulusan hati, (9) berterima kasih, dan (10) kerendahan hati. Mengabolarasi dari pendapat Tilman dan Thomas Lichona tersebut dan dihubungkan dengan filsafat manajemen pendidikan karakter yang islami dan nilai-nilai luhur bangsa dan budaya, maka paling tidak ada sepuluh nilai karakter utama untuk internalisasikan yaitu: Hakikat spiritualitas ialah pandangan pribadi dan perilaku yang mengekspresikan rasa keterkaitan, tujuan dan makna hidup dan kesadaran ke dimensi transendental (Yang Maha Tinggi) atau untuk sesuatu yang lebih besar dari diri sehingga mengerti arti dan tujuan hidup. Rasa keterkaitan dan kesadaran

\footnotetext{
${ }^{20}$ Muhammad Ali al-Shabuni, Mukhtashar Tafisr Ibnu Katsir, (Beirut: al-Maktabah al-al'Ashriyah, 2004), h. 21.

${ }^{21}$ Thomas Lickona, Education for Character, Juwa Adu Wamaungo (penerjemah), (Jakarta: Bumi Aksara, 2012), h. 98.

${ }^{22}$ Diane Tilman, Living Values Activities for Young Adults, (Jakarta: Grasindo, 2004), h. xi.
} 
bahwa segala yang dialami dalam hidup ini selalu terkait dengan yang berdimensi transcendental. Karakter spiritual menunjukkan sikap dan perilaku yang patuh dalam melaksanakan ajaran agama yang dianutnya, toleran terhadap pelaksanaan ibadah agama lain, dan hidup rukun dengan pemeluk agama lain. Ma'rifatullah adalah sebagai pilar dari karakter ini. Spiritual keagamaan atau keimanan ini adalah inti dari hati nurai moral (moral consequence). Pada hakikatnya hati nurani moral ini merupakan kekuatan ruhaniyah dan keimanan yang memberi semangat kepada seseorang untuk berbuat terpuji dan menghalanginya dari tuna karakter. Character consequence dapat menguasai dan mengawasi seseorang dalam setiap geraknya dan merupakan titik tolak seseorang untuk bersikap dan berbuat. Iman yang letaknya dalam hati akan menimbulkan konsekuensi logis terhadap tindakantindakan karakter berupa pengalaman norma-norma Islam (moral judgement), tanggung jawab moral (moral responsibility), dan ganjaran moral (moral rewards). Syekh Nawawi sangat detail menjelaskan (moral knowing) terhadap isi hati nurani moral yakni berupa keimanan.

Sebelum seseorang melakukan perbuatan positif atau negatif, pada hakikatnya dalam diri manusia ada kekuatan yang dikenal dengan suara batin/hati (conscience) untuk mendorong atau mengingatkannya. Bila meloloskan suara batin yang negatif, maka ia akan menguasasi kebaikan. Sebaliknya jika suara batin yang positif yang dilakukan, maka seseorang akan menguasai keburukan. Manurut Ahmad Amin, suara hati itu tiga tingkatan (1) Perasaan melakuan kewajiban karena takut kepada manusia, (2) Perasaaan mengharuskan mengikuti apa yang diperintahkan oleh undang-undang, meskipun sendirian atau dimuka orang banyak dan (3) perasaan seharusnya mengikut apa yang dipandang benar oleh dirinya berbeda dengan pendapat orang lain atau sesuai, menyalahai undang-undang atau berbeda. $^{23}$.

Untuk tingkatan yang ketiga inilah yang paling baik dan berkarakter. Maka tingkatan ketiga inilah yang secara terus menerus diberdayakan dan di isi dengan nilai-nilai spiritual keagamaan (ma'rifatullah) sehingga suara batin seseorang

\footnotetext{
${ }^{23}$ Amin, Ahmad, Al-Akhlak, (Jakarta, Bulan Bintang, 1975), h. 75-76.
} 
menjadi kuat dan tahan uji menghadapi pergeseran nilai yang begitu cepat di arus global ini. Dengan kekuatan spiritual keagamaan (ma'rifatullah), sekalipun undang-undangnya lemah atau ada celah untuk dilanggar, dan sekalipun tidak di lihat manusia sewaktu dia mau berbuat jahat, dia tetap melakukan kebaikan sesuai dengan nilai-nilai yang menghujam dan berurat berakar dalam jiwanya. Hati nurani moral ini melahirkan ibadah yakni hubungan baik dengan Allah, dengan manusia dan dengan alam sesuai dengan nilai-nilai Islam. Ibadah secara sadar atau tidak sadar akan mengembangkan sikap hidup, sifat-sifat, kehendak, perilaku dan akhlak terpuji dan mengurangi akhlak tercela. Hakikat ibadah adalah jalan hidup yang mencakup seluruh aspek kehidupan serta segala yang dilakukan manusia berupa perkataan, perbuatan, perasaan bahkan bagian apapun dari perilakunya untuk mengabdi dan mencari ridha Allah.

Karakter hikmah ialah kepandaian menggunakan akal budinya/pertimbangan yang baik dan kecakapan bertindak (pengalaman dan ilmunya) dalam menghadapi sesuatu. Lahirnya hikmah itu ialah karena dia berilmu dan berpengalaman. Kebijaksanaan memungkinkan seseorang membuat keputusan masuk akal yang baik bagi kita dan orang lain. Pribadi tidak dapat melakukan yang benar jika ia tidak lebih dahulu melihat dengan "benar". Karakter hikmah mengandung makna, "mengambil ikan dari sungai, sementra sungai tidak terkotori oleh apapun karena kedalaman ilmu dan pengalamannya". Falsafah air mengalir bagian dari karakter al-hikmah.

Tanggungjawab merupakan sikap dan prilaku seseorang untuk melaksanakan tugas dan kewajibannya, yang seharusnya dia lakukan, terhadap diri sendiri, masyarakat, lingkungan (alam, sosial dan budaya), negara dan Tuhan. Tanggung jawab adalah ciri manusia yang beradab. Manusia merasa bertanggung jawab karena ia menyadari akibat baik atau buruk perbuatannya itu, dan menyadari pula bahwa pihak lain memerlukan pengadilan atau pengorbanan.Tanggung jawab merupakan suatu bentuk lanjutan dari spiritual keagamaan (ma'rifatullah). Setiap orang bertanggungjawab terhadap apa ia katakan dan lakukan dalam tindakan manusiawi secara mandiri dan integritas. Anugerah Tuhan kepada manusia berupa berbagai potensi internal (akal, 
nafs/nyawa, hati, dan fisik yang dihidupi oleh ruh), dan kebebasan memilih untuk bertindak, dan diutus para rasul yang membawa kitab, menjadikan manusia bertanggungjawab terhadap apa yang ia katakan dan lakukan secara mandiri. Dalam hadis shaheh disebutkan bahwa "Setiap kamu adalah pemimpin dan bertanggungjawab terhadap yang dipimpinnya". Dengan nilai tanggung jawab ini akan berimplikasi kepada nilai lain yakni integritas dan kemandirian. Orang yang bertanggung jawab mempunyai pribadi yang utuh dan bulat (integritas) dan mandiri (berdiri sendiri atau tidak tergantung kepada orang lain dalam melaksanakan nilai-nilai kebaikan.

Nilai menghargai dan nilai hormat merupakan kelanjutan dari nilai spiritualitas keagamaan dan tanggung jawab. Menghormati adalah sikap dan tindakan yang mendorong dirinya untuk menghasilkan sesuatu yang berguna bagi masyarakat, dan mengakui, serta menghormati keberhasilan orang lain. Penghargaan dan rasa sayang dan cinta ditekankan dalam Islam. Dalam hadis dikatakan, bahwa tidak sempurna iman seseorang sehingga ia menghargai, mencinta, dan menyayangi saudaranya (orang lain) sebagaimana ia menghargai, mencintai dan menyayangi dirinya sendiri. Rasa hormat berarti menunjukkan penghargaan kita terhadap harga diri sendiri, harga diri orang lain ataupun hal lain selain diri sendiri. Sumber dari rasa hormat lahir karena (1) manusia berasal dari asal yang satu yakni Adam dan Hawa, (2) merasa sebagai hamba Allah yang sama harkat dan martabatnya, tanpa memandang jenis kelamin, kesukuan, dan lain-lain. Tinggi rendahnya manusia hanya ada dalam pandangan Allah yang tahu kadar ketakqwaannya (QS/. Al-Hujurat: 13), dan (3) sama-sama melaksanakan kewajiban kepada Allah dan merasa bagian integratif-interkonektif dari orang lain. Tabah berarti kemampuan seseorang menahan diri dari segala sesuatu yang tidak di sukai karena mengharap ridha Allah. Dalam Islam dijelaskan bahwa yang di maksud sabar ialah kondisi mental untuk dapat mengendalikan nafsu dan menahan diri dalam menanggung suatu penderitaan, baik dalam menemukan sesuatu yang tidak di ingini ataupun dalam bentuk kehilangan sesuatu yang disenangi. Sabar adalah sikap batin yang memampukan seseorang mengatasi atau menahan kesukaran, kekalahan, kesusahan, dan derita. 
Kasih sayang adalah rasa yang timbul dalam hati yang tulus untuk mencintai, menyayangi, serta memberikan kebahagian kepada orang lain, atau siapapun yang disayanginya. Dasar sayang melebihi dari rasa cinta. Rasa cinta lebih dekat kepada faktor biologis dan bersifat kebendaan. Sedangkan sayang melebih itu semua yakni mengandung nilai-nilai luhur, abstrak, abadi, dan spiritual. Kasih sayang melampaui keadilan, ia memberikan lebih daripada persyaratan keadilan dan berkorban demi orang lain. Empati, kebaikan, kemurahan hati, pengabdian, kesetiaan, patriotisme, dan kesediaan memaafkan merupakan perwujudan dari "Karakter Kasih Sayang”. Dalam QS. Thaha: $44^{24}$ diabadikan bagaimana sikap toleran, lembut dan penuh makna Nabi Musa as dan Nabi Harun as terhadap Firaun yang kejam, bengis, puncak kesombongan bahkan mengakui dirinya sebagai Tuhan. Menurut Ibnu Katsir, bahwa kata-kata yang digunakan Nabi Musa as dan Nabi Harun as terhadap Firaun dalam menyeru kepada jalan Allah adalah kata-kata yang halus (raqiq), lembut (layyin), mudah dicerna (sahl), dan ramah bersahabat (rafiq). Hal itu dilakukan supaya lebih berpengaruh dalam jiwa, lebih dapat diterima dan lebih berguna dan bermanfaat. 25

Kerja keras adalah kegiatan yang dikerjakan secara sungguh-sungguh dan focus tanpa mengenal lelah atau berhenti sebelum target atau tujuan kerja tercapai dan selalu mengutamakan atau memperhatikan kepuasan hasil pada setiap kegiatan yang dilakukan. Kesuksesan yang sesungguhnya tercapai adalah karena kerja keras. Maka kerja keras meliputi prakarsa, semangat, kerajinan, ulet, teliti, tekun, komitmen kepada tujuan, disiplin dan mengakar dalam berpikir. Setiap muslim diperintahkan kerja keras. Jika seseorang selesai melakukan suatu pekerjaaan, cepat bergegaslah untuk mengerjakan lainnya (QS. Insyirah: 7-8). Demikian juga seseorang dilarang keras menggantungkan hidupnya pada orang lain, apalagi meminta-minta. Dalam hadis disebutkan bahwa "Sesungguhnya amal yang paling dicintai Allah adalah yang terus menerus atau istiqomah (kontinyu/disiplin) meskipun sedikit (HR. Bukhari dan Muslim)"

\footnotetext{
24"maka berbicaralah kamu berdua kepadanya dengan kata-kata yang lemah lembut, mudah-mudahan ia ingat atau takut".

${ }^{25}$ Muhammad Ali al-Shabuni, Muktashar..., h. 383.
} 
Karakter ikhlas ialah tindakan yang sungguh-sungguh dan bersih hati, benar-benar keluar dari hati yang suci. Hati yang suci itu hanya berisi karena Tuhan. Ikhlas ialah bersikap, berpikir, meyakini dan bertindak semata-mata karena Allah. Ikhlas melekat pada hati nurani moral, setia pada nurani moral, menepati janji, jujur dan berpegang teguh pada apa yang diyakini. Ikhlas mengatakan kebenaran kepada diri sendiri. Sedangkan kejujuran, mengatakan kebenaran kepada orang lain. Karakter yang ingin dibangun adalah "karakter yang berkamampuan dan berkebiasaan memberikan yang terbaik, giving the best, sebagai prestasi yang dijiwai oleh nilai-nilai keikhlasan dan kejujuran.

Rendah hati artinya sikap mental pribadi yang bijak pada seseorang, dapat memposisikan sama antara dirinya dengan orang lain, merasa tidak lebih pintar, baik, mahir, serta tidak merasa lebih tinggi atau mulia, juga dapat menghargai orang dengan tulus. Karakter rendah hati merasa sama dengan orang lain sebagai ciptaan Tuhan yang memiliki keunikan dan keistimewaan masing-masing. Dengan sikap batin seperti itu menjadikan orang lain merasa penting dalam kehidupannya. Karena sesungguhnya setiap pribadi memiliki keistimewaan masing-masing. Dan setiap orang juga adalah spesial, unik, serta berhak untuk dihargai. Setiap manusia didunia ini adalah pribadi yang harus diperlakukan khusus dan tidak untuk dibeda-bedakan. Kerena manusia juga adalah makhluk yang sangat misterius dan tak terduga.

Sikap mental ini membuat seseorang sadar akan kekurangan dan membuatnya berusaha menjadi yang terbaik dan bermanfaat. Kata Nabi SAW: Sebaik-baik manusia ialah yang baik dan manfaat bagi orang lain. Nilai rendah hati sebagai lawan dari sombong. Hakikat sombong ialah merasa dirinya serba cukup dan karenanya menghina orang lain bahkan dirinya sendiri. Karena salah satu dari induk kejahatan ialah kesombongan. Iblis di laknat oleh Allah karena kesombongannya. Karena dengan kesombongan, seseorang akan merasa dirinya serba cukup, tidak mau meningkatkan kualitas diri, dan bahkan menghina dan berbuat zalim terhadap dirinya dan kepada orang lain. Bersahabat atau silaturrahmi adalah hubungan kasih sayang antara sesama mukmin, atau sesama manusia karena pada hakikatnya manusia itu adalah saudara dan berasal dari 
Adam. Dalam QS. Al Hujurat10 yang artinya, “Sesungguhnya orang-orang yang beriman (mukminin) adalah saudara." Data empiris menunjukkan bahwa orang sukses justru ditentukan sejauh mana seseorang santun dalam berkomunikasi, bersilaturrahim dan bertindak. Intelegensi hanya salah satu faktor saja untuk menuju sukses. Dalam penelitian di AS dari 20 kualitas yang dianggap penting dari seorang lulusan perguruan tinggi untuk seseorang menjadi sukses peringkat atas ialah karakter kemampuan berkomunikasi atau silaturrahim, integritas dan kemampuan berkerjasama dengan orang lain. ${ }^{26}$ Dalam agama sangat dikutuk orang-orang yang memutuskan silaturrahmi walau kepada orang tidak suka kepada kita sekalipun. Pribadi bersilaturrahmi ialah menyukai cara-cara positif, seperti menghormati orang lain, santun, perhatian, mencintai, membantu, hingga mudah diterima, dan tidak pernah berusaha menguasai orang lain.

\section{Metode Penelitian}

Penelitian ini menggunakan metode filsafat dengan paradigm HolistikIntegratif-Interkonektif.

\section{Pembahasan}

Filosufi yang mendasar sub bahasan ini bahwa setiap manusia adalah homo educandum (dapat dipengaruhi) dan homo educandus (dapat mempengaruhi) dalam pembentukan karakter. Untuk itu kesepuluh nilai karakter tersebut di atas, dapat diajarkan secara holistik-integratif-interkonektif dengan lima rukun strategi. Kebiasaan adalah yang memberi sifat dan jalan yang tertentu dalam pikiran, keyakinan, keinginan dan percakapan; kemudian jika ia telah tercetak dalam sifat ini, seseorang sangat suka kepada pekerjaaannya kecuali merubahnya dengan kesukaran. Menurut Ahmad Amin kebiasaan baru dapat menjadi karakter jika seseorang senang atau ada keinginan kepada sesuatu yang dibiasakan dan diterimanya keinginan itu, dan diulang-ulang keinginan dan penerimaan itu secukupnya. ${ }^{27}$ Kebiasaan tidak hanya terbatas pada perilaku, tetapi juga kebiasaan berpikir, berkeyakinan, dan berperasaan yang positif. Sifat

\footnotetext{
${ }^{26}$ Ichsan S. Putra dan Ariyanti, Sukses Dengan Soft Skill, (Bandung: Direktorat Pendidikan ITB Bandung, 2005), h. 4-5. h. 27 .

${ }^{27}$ Ahmad Amin, Al-Akhlaq, Farid Ma'ruf (penterjemah), ( Jakarta: Bulan Bintang, 1975),
} 
system urat saraf itu menerima perubahan. Menurut Ibrahim Alfikiy, kebiasaan adalah pikiran yang diciptakan seseorang dalam benaknya, kemudian dihubungkan dengan perasaan dan diulang-ulang hingga akal meyakininya sebagai bagian dari perilakunya. Hukum pembiasaan itu melalui enam tahapan yakni (1) berpikir, (2) perekaman, (3) pengulangan, (4) penyimpanan, (5) pengulangan dan (6) kebiasaan. ${ }^{28}$ Pembiasaan dapat dilakukan baik sebelum peserta didik mengerti atau dimengerti tentang kebaikan yang dilakukannya.

Dalam hadis, disebutkan, "Perintahlah anak-anakmu menjalankan ibadah salat jika mereka sudah berusia tujuh tahun. Dan jika mereka sudah berusia sepuluh tahun, maka pukullah mereka jika tidak mau melaksanakannya dan pisahkanlah tempat tidur mereka" (HR. al-Hakim). Rentang waktu antara 7 sampai dengan 10 tahun yakni 3 tahun mengandung makna pembiasaan melakukan ibadah dan kebajikan. Karena anak umur 7 tahun (belum dewasa) belum ada kewajibannya melaksanakan ibadah salat dan ibadah-ibadah lainnya. Dari perintah salat, dapat disamakan dengan ibadah puasa, dan perbuatan kebajikan lainnya, seperti kejujuran, rasa hormat, toleransi, dan lain-lain. Tujuannya adalah agar anak terbiasa sekaligus menjadi karakternya untuk melakukan yang baik, sehingga ketika tumbuh dewasa, ia telah terbiasa dan terpatri dalam jiwanya melakukan nilai-nilai kebaik, terhadap Allah, manusia dan diri sendiri. Di samping itu, anak akan mendapatkan kesucian rohani, gerakan refleks dan kesehatan jasmani, kebaikan akhlak, perkataan, dan perbuatan di dalam ibadah-ibadah itu. Begitu kuatnya pembiasaan ini, para ulama fiqh pun menciptkan kaidah fiqh kulliyah yakni "Adat kebiasaaan dapat ditetapkan sebagai hukum". Menurut Williah Kilpatrick, salah satu penyebab ketidak mampuan seseorang berlaku baik meskipun ia telah memiliki pengetahuan tentang kebaikan itu adalah karena ia tidak terlatih (terbiasa) untuk melakukan kebaikan. ${ }^{29}$

Kebiasaaan-kebiasaan yang baik yang dilakukan seseorang atau hal-hal yang baik yang belum dilakukan, harus diberi pemahaman dan ilmu tentang nilainilai manfaat, logika dan akibat dari nilai baik yang dilakukan. Dengan demikian,

\footnotetext{
${ }^{28}$ Ibrahim Elfiky, Terapi Beripikir Positif, (Jakarta: Zaman, 2012), h. 91.

${ }^{29}$ Abdul Majid dan Dian Andayani, Pendidikan Karakter Perspektif Islam, (Bandung: PT Remaja Rosdakarya, 2011), h. 31.
} 
seseorang mencoba mengetahui, memahami, menyadari, dan berpikir logis tentang arti dari suatu nilai-nilai dan perilaku yang baik, kemudian mendalaminya dan menjiwainya. Lalu nilai-nilai yang baik itu berubah menjadi power intrinsik yang berurat berakar dalam diri seseorang. Mengajarkan yang baik, yang adil, yang bernilai, berarti memberikan pemahaman dengan jernih kepada peserta didik apa itu kebaikan, keadilan, kejujuran, toleransi, dan lain-lain. Boleh jadi seseorang berprilaku baik, adil, toleransi, tanpa disadarinya sekalipun secara konseptual tidak mengetahui dan tidak menyadari apa itu perilaku baik, atau apa itu keadilan, atau apa itu kejujuran.

Perilaku berkarakter mendasarkan diri pada tindakan sadar si subjek, bebas memilih malakukan atau tidak dan berpengetahuan yang cukup tentang apa yang dilakukan dan dikatakannya. Meskipun tampaknya mereka tidak memiliki konsep jernih tentang nilai-nilai tersebut, sejauh tindakan itu dilakukan dalam keadaan sadar dan bebas, tindakan tersebut dalam arti tertentu telah dibimbing oleh pemahaman tertentu. Tanpa ada pemahaman dan pengertian, kesadaran dan kebebasan tidak mungkin ada sebuah tindakah berkarakter. Dalam Islam pun sebuah tindakan diminta pertanggungjawabannya apabila yang melakukan itu sudah dewasa, berakal (berpengetahuan), dalam keadaan sadar, dan ada kebebasan untuk memilih. Sebuah tindakan yang tidak disadari, tidak dibimbing oleh pemahaman tertentu, dan tidak ada kebebasan, maka tindakan itu tidak akan memiliki makna bagi individu tersebut, sebab ia sendiri tidak menyadari dan tidak mengetahui makna dan akibat tindakan yang dilakukannya. Demikian juga sebuah tindakan yang tidak bebas dan tidak disadari serta tidak dibimbing oleh pengetahuan tentangnya, adalah tindakan instingtif atau ritual yang lebih dekat pada cara bertindak binatang. QS. Al-Zumar: $9,{ }^{30}$ sangat menekankan tentang perbedaan orang yang berilmu dengan orang yang tidak berilmu. Paling tidak orang yang berilmu bila melakukan kejahatan, masih ada harapan untuk sadar dan

\footnotetext{
${ }^{30}$ (Apakah kamu hai orang musyrik yang lebih beruntung) ataukah orang yang beribadah di waktu-waktu malam dengan sujud dan berdiri, sedang ia takut kepada (adzab) akhirat dan mengharapkan rahmat Tuhannya? Katakanlah: "Adakah sama orang-orang yang mengetahui dengan orang-orang yang tidak mengetahui?" Sesungguhnya orang yang berakallah yang dapat menerima pelajaran.
} 
bertobat, karena ia tau tentang kekeliruannya. Berbeda dengan orang yang tidak tau, jika melakukan kesalahan, sulit diharapkan sadarnya, atau justru menjadi karakternya karena ketidak tahuannya itu.

Lahirnya moral loving berawal dari mindset (pola piker-hati). Pola pikir yang positif terhadap nilai-nilai kebaikan akan merasakan manfaat dari berprilaku baik itu. Jika seseorang sudah merasakan nilai manfaatnya akan melahirkan rasa cinta dan sayang. Jika sudah mencintai hal yang baik, maka segenap dirinya akan berkorban demi melakukan yang baik itu. Dengan rasa cinta dalam melakukan kebaikan, seseorang akan menikmati dan nyaman dalam posisi itu. Dari berpikir dan berpengetahuan yang baik secara sadar lalu akan mempengaruhi dan akan menumbuhkan rasa cinta dan sayang. Perasaan cinta kepada kebaikan menjadi power dan engine yang bisa membuat orang senantiasa mau berbuat kebaikan bahkan melebihi dari sekedar kewajiban sekalipun harus berkorban baik jiwa dan harta. Lama-lama tumbuh kesadaran bahwa, orang mau melakukan kebajikan karena dia cinta dengan perilaku kebaikan itu.

Setiap orang butuh keteladanan dari lingkungan sekitarnya. Manusia lebih banyak belajar dan mencontoh dari apa yang ia lihat dan alami. Perangkat belajar pada manusia lebih efektif secara audio-visual. Fitrah manusia pada dasarnya ingin mencontoh. Salah satu makna hakiki dari terma tarbiyah adalah mencontoh atau imitasi. Keteladanan yang paling berpengaruh adalah yang paling dekat dengan diri kita. Orang tua, karib kerabat, pimpinan masyarakat dan siapa pun yang sering berhubungan dengan seseorang terutama idolanya, adalah menentukan proses pembentukan karakter baik-kuat atau jelek-lemah. Jika lingkungan social berprilaku jujur, amanah, berakhlak mulia, berani, dan menjauhkan diri dari perbuatan yang bertentangan dengan nilai-nilai luhur agama dan bangsa, maka seseorang akan seperti itu. Sebaliknya seseorang, bagaimana pun besar usaha yang dipersiapkan untuk kebaikannya, bagaimana pun suci fitrahnya, ia tidak akan mampu memenuhi prinsip-prinsip kebaikan dan nilai-nilai lurur agama, selama ia tidak melihat lingkungan sosialnya sebagai teladan dari nilai-nilai moral yang tinggi. Adalah sesuatu yang sangat mudah bagi seseorang termasuk orang tua, yaitu mengajari anak dan mahasiswa dengan nilai-nilai luhur, 
akan tetapi adalah sesuatu yang teramat sulit bagi mereka untuk melaknakannya ketika ia melihat orang yang memberikan pengarahan dan bimbingan kepadanya tidak mengamalkannya. Bukankah Tuhan berfirman dalam QS. Ash Shaff: 3: "Amat besar kebencian di sisi Allah bahwa kamu mengatakan apa-apa yang tiada kamu kerjakan". Begitu tertancapnya pengaruh keteladanan ini, dapat diikuti dialog antara Nabi SAW dengan sahabat bernama Handzalah. ${ }^{31}$. Itulah sebabnya salah satu keberhasilan Nabi SAW dalam menyampaikan risalahnya adalah karena dia sendiri menjadi keteladanan paripurna bagi umatnya ( QS. Al-Ahazab: 21).

Tobat pada hakikatnya ialah kembali kepada Allah setelah melakukan kesalahan/dosa. Tuhan mencintai hambanya yang tobat dan tazkiyatu nufus (mensucikan diri) (QS. Al-Baqarah: 222). Dalam tobat, ingatan, pikiran, perasaan, dan hati nurani, secara total digunakan untuk menangkap makna dan nilai yang dilakukan selama ini, menemukan hubungan dengan Tuhannya, dan kesiapan menanggung konsekwensi dari tindakan taubatnya. Ada tiga langkah dalam tobat, (1) takhalli yakni pengekangan segala hawa nafsu dan mengkosongkan hati dari segala-galanya, kecuali dari diri yang dikasihi yaitu Allah SWT. Takhalli berarti mengkosongkan atau memersihkan diri dari sifatsifat tercela dan dari kotoran penyakit hati yang merusak. Karenanya pelaku tobat pasti menyesali perbuatan salahnya, minta maaf kepada Tuhan atau manusia atas segala dosanya. (2) Tahalli berarti berhias diri dengan sifat dan sikap terpuji serta pebuatan yang baik. Berusaha agar dalam setiap gerak prilaku selalu berjalan diatas ketentuan agama, baik kewajiban luar maupun kewajiban dalam atau ketaan lahir maupun batin. (3) Tajalli, seseorang hatinya terbebaskan dari tabir (hijab) yaitu sifat-sifat kemanusian atau memperoleh nur yang selama ini tersembunyi (ghaib) atau fana segala selain Allah ketika nampak (tajalli) wajah-Nya. Dari tiga langkah itu pelaku tobat akan membentuk kesadaran tentang hakikat hidup, tujuan

\footnotetext{
${ }^{31}$ Handzalah ketika bersama keluarganya merasakan perasaan yang berbeda dengan ketika bersama Rasulullah dalam segi kejernihan, kepatuhan dan ketakutannya kepada Allah, ia melihat bahwa ini merupakan bentuk kemunafikan. Dia pun keluar menyelusuri jalan seraya berkata kepada diri sendiri: "Handzalah telah berbuat munafik!" Kemudian sampailah dia kepada Rasulullah dan menjelaskan apa yang terjadi, apa yang dirasakan dari perbedaan situasi spritual antara bersama keluarga dan bersama Rasulullah. Rasulullah SAW mengomentari dengan sabda beliau: "Jika kondisimu tetap seperti ketika bersamaku, sungguh engkau akan disalami malaikat di jalan-jalan, akan tetapi wahai Handzalah 'sesaat dan sesaat'
} 
hidup, melahirkan optimisme, nilai kebajikan, nilai-nilai yang di dapat dari berbagai tindakannya, manfaat dan kehampaan tindakannya, dan lain-lain sedemikian rupa, sehingga seseorang dibawa maju untuk melakukan suatu tindakan dalam paradigma baru dan karakter baru di masa-masa akan datang. Gambar berikut ialah Paradigma holistik-integratif-interkonektif dalam hal level strategi pembentukan karakter:

\section{Daftar Pustaka}

Abdul Majid dan Dian Andayani, Pendidikan Karakter Perspektif Islam, Bandung: PT Remaja Rosdakarya, 2011.

Abdullah Munir, Pendidikan Karakter, Yogyakarta: Pustaka Insan Madani, 2010.

Baqi, Muhammad Fuad Abdul, Al-Mu'jam al-Mufakhras li Alfadz al-Quran alKarim, Beirut: Dar al-Fikr, 1987

Bantani al, Nawawi, Syekh, Maraqi al-'Ubudiyah, Syarh 'ala Matn Bidayah alHidayah, Semarang: Toha Putra, tth.

Bantani al, Nawawi, Syekh, Qami' al-Tugyan 'Ala Manzumah Sya'ab al-Iman, Semarang: Thaha Putra, th.

Bambang Q-Anees dan Adang Hambali, Pendidikan Karakter Berbasis Al-Quran, Bandung: Simbiosa Rekatama Media, 2008.

Bigge, Morris L., Learning Theories for Teachers, USA: Harper and Row, Publisher, Inc, 1982.

Doni Koesoema A, Pendidikan Karakter Strategi Mendidik Anak di Zaman Global, Jakarta: PT Gramedia, 2010.

Elfky, Ibrahim, Terapi Berpikir Positif, Jakarta: Zaman, 2012.

Eko Endarmoko, Tesaurus Bahasa Indonesia, Jakarta: PT Gramedia Utama, 2008

Ichsan S. Putra, dkk, Sukses dengan Soft Skills, Bandung: Direktorat Pendidikan ITB, 2005.

Jalal, Abdul Fattah, Min al-Usul al-Tarbiyah fi al-Islam, Mesir: tpn., 1977.

Jalaluddin Rahkmat, Islam Aktual, Bandung: Mizan, 1992.

Lichona, Thomas, Education for Character, Juwa Adu Wamaungo (penerjemah), Jakarta: Bumi Aksara, 2012.

Nahlawi al, Abdurrahman, Usul al-Tarbiyah al-Islamiyah wa Asalibuha fi al-Bait wa al-Madrasah wa al-Mujtama', Beirut: Mutabi’ al-Mustaqil, 1996. 
M. Amin Abdullah, Paradigma dan Implementasi Pendekatan IntegrasiInterkoneksi dalam Kajian Pendidikan Islam, Yogyakarta: Pascasarjana UIN Sunan Kalijaga, 2014.

Masnur Muslich, Pendidikan Karakter, Menjawab Tantangan Krisis Multidimensial, Jakarta: Bumi Aksara, 2011.

Maragustam, Mencetak Pembelajar Menjadi Insan Paripurna (Falsafah Pendidikan Islam), Yogyakarta: Nuha Litera, 2010.

Maragustam, Pemikiran Pendidikan Syekh Nawawi al-Bantani, Yogyakarta: CV Datamedia, 2007.

Maragustam, Filsfat Pendidikan Islam Menuju Pembentukan Karakter Menghadapi Arus Global, Yogyakarta: Kurnia Kalam Semestra, 2015.

Maragustam (editor), Implementasi Pendekatan Integratif-Interkonektif Dalam Kajian Pendidikan Islam, Yogyakarta: Pascasarjana UIN Sunan Kalijaga, 2014.

Muhammad Quraish Shihab, Wawasan al-Quran, Bandung: Mizan, 1997.

Musa, Muhammad Yusuf, Al-Quran wa al-Falasifah, Kairo Mesir: Dar alMa'arif, 1958.

Rahman, Fazlur, Major Themes of the Qur'an, Chicago: Bibliotheca Islamica, Minneapolis, 1980.

Shadr al, Muhammad Baqir, Sejarah Dalam Perspektif Al-Qur'an, Sebuah Analisis, Jakarta: Pustaka Hidayah, 1993.

Sri Narwati, Pendidikan Karakter, Pengintegrasian 18 Nilai Pembentuk Karakter dalam Mata Pelajaran, Yogyakarta: Familia, 2011.

Sulistyorini, Manajemen Pendidikan Islam (Konsep, Strategi, dan Aplikasi), Yogyakarta: Sukses Offset, 2009.

Sofwan Manaf, Pola Manajemen Penyelenggaraan Pondok Pesantren, Jakarta, Dirjen Pembinaan Kelembagaan Agama Islam Depag RI., 2001.

Shabuni al, Muhammad Ali, Mukhtashar Tafsir Ibnu Katsir, Beirut: al-Maktabah al-al-'Ashriyah, 2004.

Syafaruddin, Manajemen Lembaga Pendidikan Islam, Jakarta: PT. Ciputat Press, 2005.

Tilman, Diane, Living Values Activities for Young Adults, Jakarta: Grasindo, 2004.

W.J.S. Poerwadarminta, Kamus Umum Bahasa Indonesia, Jakarta: Balai Pustaka, 2005.

Yasien Mohammad, Insan Yang Suci, Konsep Fitrah Dalam Islam, Bandung: Mizan, 1997. 